\title{
Synthesis of Valsartan via Decarboxylative Biaryl
}

\section{Coupling}

\author{
Lukas J. Gooßen*, Bettina Melzer \\ Institut für Organische Chemie, TU Kaiserslautern, \\ Erwin-Schrödinger-Straße, Building 54, D-67663 Kaiserslautern, \\ Phone: +49631205 2046, Fax: +496312053921
}

\section{Supporting Information}

\begin{tabular}{|l|r|}
\hline General Procedures & S2 \\
\hline Spectroscopic data & S2-S6 \\
\hline 2c) 1H, 13C NMR spectrum, elemental analysis, MS & S7 \\
\hline 4a) 1H, 13C NMR spectrum, elemental analysis, MS & $\mathrm{S} 8$ \\
\hline 4b) 1H, 13C NMR spectrum, elemental analysis, MS & $\mathrm{S} 9$ \\
\hline 4c)1H, 13C NMR spectrum, elemental analysis & $\mathrm{S} 10$ \\
\hline 6)1H, 13C NMR spectrum, elemental analysis & $\mathrm{S} 11$ \\
\hline 8)1H, 13C NMR spectrum, elemental analysis & $\mathrm{S} 12$ \\
\hline 1d)1H, 13C NMR spectrum, elemental analysis & $\mathrm{S} 13$ \\
\hline 1b) $1 \mathrm{H}, 13 \mathrm{C}$ NMR spectrum, elemental analysis, MS & $\mathrm{S} 14$ \\
\hline
\end{tabular}


General: Reactions were performed under a nitrogen atmosphere in oven-dried glassware containing a tefloncoated stirrer bar and dry septum. Solvents were freshly distilled. GC analyses were carried out using a capillary column (Phenyl Methyl Siloxane $30 \mathrm{~m}$ x 320 x 0.25, 100/2.3-30-300/3) and a time program beginning with $2 \mathrm{~min}$. at $60{ }^{\circ} \mathrm{C}$, followed by $30{ }^{\circ} \mathrm{C} / \mathrm{min}$. ramp to $300{ }^{\circ} \mathrm{C}$, then $3 \mathrm{~min}$. at this temp. Column chromatography was performed using an MPLC system and RediSep packed column (12 g). TLC analyses were performed on commercial Kieselgel 60 F254 silica gel plates. NMR spectra were obtained using $\mathrm{CDCl}_{3}$ or DMSO-d 6 as solvent, with proton and carbon resonances at $400 \mathrm{MHz}$ or $600 \mathrm{MHz}$ and $100 \mathrm{MHz}$ or $150 \mathrm{MHz}$, respectively.

\section{Synthesis of starting materials.}

Synthesis of 2-cyanobenzoic acid (2c) [CAS: 3839-22-3]; The synthesis follows the literature procedure of T. Yoneta, S. Shibahara, S. Fukatsu, S. Seki, Bulletin of the Chemical Society of Japan 1978, 51, 3296-3297; and N. Miyaura, Top. Curr. Chem., 219, Springer-Verlag, Berlin Heidelberg, 2002, 131-209. An oven-dried flask was charged with phthalic anhydride $(27.7 \mathrm{~g}, 187 \mathrm{mmol})$ and THF $(100 \mathrm{~mL})$. Ammonia was bubbled through the reaction solution for $15 \mathrm{~min}$. under vigorous stirring at room temperature. The resulting white solid was filtered off, washed successively with small amounts of water and hot acetone, then dried under high vacuum to yield a white ammonium salt $(21.1 \mathrm{~g}, 62 \%)$. This salt was dissolved in pyridine $(400 \mathrm{~mL})$ and stirred at room temperature for $30 \mathrm{~min}$., then acetic anhydride $(32.6 \mathrm{~g}, 319.7 \mathrm{mmol})$ was added and the reaction mixture was stirred until a clear solution formed. The solvent was removed under reduced pressure, and the remaining solid was redissolved in ethyl acetate $(500 \mathrm{~mL})$. The organic phase was washed twice with aqueous $\mathrm{HCl}$ solution $(1 \mathrm{~N})$ and brine, and dried over $\mathrm{MgSO}_{4}$. The solvent was removed, and the solid was recrystallized from ethyl acetate to yield $2 \mathrm{c}$ as a white solid (14.6 g, $72 \%)$. 1H-NMR (400 MHz, DMSO-d $\left.\mathrm{d}_{6}\right): \delta=8.06-8.11(\mathrm{~m}, 1 \mathrm{H}), 7.94-7.99(\mathrm{~m}$, 1H), 7.76-7.84 (m, 2H) ppm. 13C-NMR (101 MHz, DMSO-d $\left.)_{6}\right): \delta=165.7,135.6,133.7,133.5,131.5,118.2$, 112.1 ppm. Anal. Calcd for $\mathrm{C}_{8} \mathrm{H}_{5} \mathrm{NO}_{2}: \mathrm{C}, 65.3 ; \mathrm{H}, 3.4 ; \mathrm{N}, 9.5$. Found: C, 65.1; H, 3.2; N, 9.5. MS (Ion trap, EI): $\mathrm{m} / \mathrm{z}(\%)=147\left[\mathrm{M}^{+}\right](100), 104(81), 76(95), 66(8), 50(52)$.

Synthesis of 2-(4-bromophenyl)-1,3-dioxolane (7c) [CAS: 10602-01-4]; The synthesis follows the literature procedure of G. Drefahl, D. Lorenz, J. Prakt. Chem. 1964, 24, 106-111. An oven-dried flask, equipped with a dropping funnel filled with molecular sieves, was charged with 4-bromobenzaldehyde $(2.8 \mathrm{~g}, 15.0 \mathrm{mmol})$, 4toluenesulfonic acid $(6.3 \mathrm{mg}, 0.03 \mathrm{mmol})$, ethan-1,2-diol $(1.2 \mathrm{~g}, 19.0 \mathrm{mmol})$ and toluene $(20 \mathrm{~mL})$. The reaction mixture was refluxed over-night (15h), then cooled, washed successively with saturated aqueous $\mathrm{NaHCO}_{3}$, and water, and dried over $\mathrm{MgSO}_{4}$. The toluene was distilled off. The crude yellow product was purified by Kugelrohrdistillation to yield compound $3 \mathbf{c}$ as a colorless liquid $\left(3.0 \mathrm{~g}, 88 \%\right.$ ). Anal. Calcd for $\mathrm{C}_{9} \mathrm{H}_{9} \mathrm{BrO}_{2}$ : $\mathrm{C}, 47.2 ; \mathrm{H}, 3.9$.

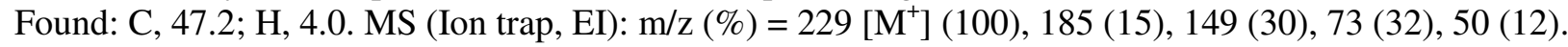

\section{Representative procedure for the biaryl synthesis.}

Synthesis of 2-cyano-4'-methylbiphenyl (4a) [CAS: 114772-53-1]; An oven-dried $20 \mathrm{~mL}$ crimp top vial was charged with copper(II) oxide $(11.9 \mathrm{mg}, 0.15 \mathrm{mmol})$, potassium carbonate $(151.1 \mathrm{mg}, 1.00 \mathrm{mmol})$, potassium fluoride $(29.1 \mathrm{mg}, 0.50 \mathrm{mmol}), 1,10$-phenanthroline $(27.0 \mathrm{mg}, 0.15 \mathrm{mmol}), 2$-cyanobenzoic acid $(176.0 \mathrm{mg}$, $1.20 \mathrm{mmol})$, palladium(II) bromide $(5.3 \mathrm{mg}, 0.02 \mathrm{mmol})$, triphenylphosphine $(5.2 \mathrm{mg}, 0.02 \mathrm{mmol})$ and ground $3 \AA$ molecular sieves $(250 \mathrm{mg})$. The reaction vessel was closed with a septum cap, evacuated and flushed with nitrogen three times. Subsequently, a solution of 4-bromotoluene $(171.0 \mathrm{mg}, 1.00 \mathrm{mmol})$ and the internal standard $n$-tetradecane $(50 \mu \mathrm{L})$ in quinoline $(1.5 \mathrm{~mL})$ was added via syringe. The resulting solution was stirred for $24 \mathrm{~h}$ at $170{ }^{\circ} \mathrm{C}$, then poured into aqueous $\mathrm{HCl}(1 \mathrm{~N}, 20 \mathrm{~mL})$. The resulting mixture was extracted repeatedly with ethyl acetate (20 mL portions). The combined organic layers were washed with water and brine, dried over $\mathrm{MgSO}_{4}$, filtered, and the volatiles were removed in vacuo. The residue was purified by column chromatography $\left(\mathrm{SiO}_{2}\right.$, ethyl acetate / hexane 1:5), yielding 4a as a yellow solid (138.3 mg, $71 \%)$. 1H-NMR (400 MHz, CDCl $\left.{ }_{3}\right): \delta=$ $7.77\left(\mathrm{~d},{ }^{3} J=7.9 \mathrm{~Hz}, 1 \mathrm{H}\right), 7.65\left(\mathrm{td},{ }^{3} J=7.6 \mathrm{~Hz}, 1 \mathrm{H}\right), 7.53\left(\mathrm{~d},{ }^{3} J=7.3 \mathrm{~Hz}, 1 \mathrm{H}\right), 7.42-7.50(\mathrm{~m}, 3 \mathrm{H}), 7.33\left(\mathrm{~d},{ }^{3} J=7.9\right.$ $\mathrm{Hz}, 2 \mathrm{H}), 2.45$ (s, 3H) ppm. 13C-NMR $\left(150 \mathrm{MHz}, \mathrm{CDCl}_{3}\right): \delta=145.5,138.7,135.3,133.7,132.7,130.0,129.5$, 128.6, 127.3, 118.8, 111.3, 21.2 ppm. Anal. Calcd for $\mathrm{C}_{14} \mathrm{H}_{11} \mathrm{~N}$ : C, 87.0; H, 5.7; N, 7.3. Found: C, 87.1 ; H, 5.7; N, 7.3. MS (Ion trap, EI): $\mathrm{m} / \mathrm{z}(\%)=193\left[\mathrm{M}^{+}\right](100), 192(48), 165$ (29), 139 (4), 75 (4). (The data correspond to those reported in the literature: B. Sain, J. S. Sandhu, J. Org. Chem. 1990, 55, 2545-2546.) 
Synthesis of 2-cyano-4'formylbiphenyl (4b) [CAS: 135689-93-9] from 4-bromobenzaldehyde (7b). An oven-dried $20 \mathrm{~mL}$ crimp top vial equipped with a septum cap was charged with copper carbonate $(45.3 \mathrm{mg}$, $0.20 \mathrm{mmol})$, potassium carbonate $(165.9 \mathrm{mg}, 1.20 \mathrm{mmol}), 1,10$-phenanthroline $(18.0 \mathrm{mg}, 0.10 \mathrm{mmol})$ [these compounds were dried before for $3 \mathrm{~h}$ at $100^{\circ} \mathrm{C}$ under high vacuum], 2-cyanobenzoic acid (176.6 mg, $\left.1.20 \mathrm{mmol}\right)$, 4-bromobenzaldehyde ( $185.0 \mathrm{mg}, 1.00 \mathrm{mmol})$, palladium(II) bromide $(5.3 \mathrm{mg}, 0.02 \mathrm{mmol})$, triphenylphosphine (73.0 mg, $0.03 \mathrm{mmol}$ ) and ground $3 \AA$ molecular sieves $\left(250 \mathrm{mg}\right.$, dried in the microwave and for $3 \mathrm{~h}$ at $210^{\circ} \mathrm{C}$ in high vacuum) and was flushed with nitrogen. Subsequently, dry, degased quinoline (1.5 ml) was added via syringe. The resulting solution was stirred for $24 \mathrm{~h}$ at $170{ }^{\circ} \mathrm{C}$ and was then poured into an aqueous $\mathrm{HCl}$ solution $(1 \mathrm{~N}, 20 \mathrm{~mL})$. The resulting mixture was extracted repeatedly ethyl acetate $(20 \mathrm{~mL}$ portions). The combined organic layers were washed with water and brine, dried over $\mathrm{MgSO}_{4}$, filtered, and the volatiles were removed in vacuo. The residue was purified by column chromatography $\left(\mathrm{SiO}_{2}\right.$, ethyl acetate / hexane 1:1), yielding $4 \mathbf{b}$ as a light yellow solid (106.2 mg, $50 \%)$.

Synthesis of $4 \mathbf{b}$ from 2-(4-bromophenyl)-1,3-dioxolane (7c). An oven-dried $20 \mathrm{~mL}$ crimp top vial equipped with a septum cap was charged with copper(II) oxide $(11.9 \mathrm{mg}, 0.15 \mathrm{mmol})$, potassium carbonate $(1380 \mathrm{~g}$, $1.00 \mathrm{mmol})$, potassium fluoride $(32,6 \mathrm{mg}, 0.50 \mathrm{mmol}), 1,10$-phenanthroline $(27.0 \mathrm{mg}, 0.15 \mathrm{mmol})$ [these compounds were dried before for $3 \mathrm{~h}$ at $100{ }^{\circ} \mathrm{C}$ under high vacuum], 2-cyanobenzoic acid (147.1 $\left.\mathrm{mg}, 1.00 \mathrm{mmol}\right)$, 2-(4-bromophenyl)-1,3-dioxolane (7c) $(343.6 \mathrm{mg}, 1.50 \mathrm{mmol}$ ), palladium(II) bromide (5.3 mg, $0.02 \mathrm{mmol}$ ), triphenylphosphine $(5.2 \mathrm{mg}, 0.02 \mathrm{mmol})$ and ground $3 \AA$ molecular sieves $(250 \mathrm{mg}$, dried in the microwave and for $3 \mathrm{~h}$ at $210{ }^{\circ} \mathrm{C}$ in high vacuum) and was flushed with nitrogen. Subsequently, dry, degassed quinoline (1.5 ml) was added via syringe. The resulting solution was stirred for $24 \mathrm{~h}$ at $170{ }^{\circ} \mathrm{C}$ and was then poured into an aqueous $\mathrm{HCl}$ solution $(3 \mathrm{~N}, 20 \mathrm{~mL})$ and heated up to $50{ }^{\circ} \mathrm{C}$ under stirring for $2 \mathrm{~h}$. The resulting mixture was extracted repeatedly with ethyl acetate $(20 \mathrm{~mL}$ portions). The combined organic layers were washed with water and brine, dried over $\mathrm{MgSO}_{4}$, filtered, and the volatiles were removed in vacuo. The residue was purified by column chromatography $\left(\mathrm{SiO}_{2}\right.$, ethyl acetate / hexane 3:2), yielding $\mathbf{4 b}$ as a light yellow solid (167.9 $\left.\mathrm{mg}, 81 \%\right)$.

Synthesis of $4 \mathbf{b}$ from 1-bromo-(4-dimethoxymethyl)benzene (7d): An oven-dried $20 \mathrm{~mL}$ crimp top vial equipped with a septum cap was charged with copper(II) oxide $(11.9 \mathrm{mg}, 0.15 \mathrm{mmol})$, potassium carbonate $(1380 \mathrm{~g}, 1.00 \mathrm{mmol})$, potassium fluoride $(32,6 \mathrm{mg}, 0.50 \mathrm{mmol})$, [these compounds were dried before for $3 \mathrm{~h}$ at $100{ }^{\circ} \mathrm{C}$ under high vacuum], 1,10-phenanthroline $(27.0 \mathrm{mg}, 0.15 \mathrm{mmol})$ 2-cyanobenzoic acid (147.1 mg, $1.00 \mathrm{mmol}$ ), 1-bromo-(4-dimethoxymethyl)benzene $(346.6 \mathrm{mg}, 1.50 \mathrm{mmol})$, palladium(II) bromide $(5.3 \mathrm{mg}$, $0.02 \mathrm{mmol})$, triphenylphosphine $(5.2 \mathrm{mg}, 0.02 \mathrm{mmol})$ and ground $3 \AA$ molecular sieves $(250 \mathrm{mg}$, dried in the microwave and for $3 \mathrm{~h}$ at $210^{\circ} \mathrm{C}$ in high vacuum) and was flushed with nitrogen. Subsequently, dry, degased quinoline $(1.5 \mathrm{ml})$ was added via syringe. The resulting solution was stirred for $24 \mathrm{~h}$ at $170{ }^{\circ} \mathrm{C}$ and was then poured into an aqueous $\mathrm{HCl}$ solution $(3 \mathrm{~N}, 20 \mathrm{~mL})$ and heated up to $50{ }^{\circ} \mathrm{C}$ under stirring for $2 \mathrm{~h}$. The resulting mixture was extracted repeatedly with ethyl acetate $(20 \mathrm{~mL}$ portions). The combined organic layers were washed with water and brine, dried over $\mathrm{MgSO}_{4}$, filtered, and the volatiles were removed in vacuo. The residue was purified by column chromatography $\left(\mathrm{SiO}_{2}\right.$, ethyl acetate / hexane 3:2), yielding $\mathbf{4 b}$ as a light yellow solid $(165.9 \mathrm{mg}, 80 \%)$. 1H-NMR (400 MHz, $\left.\mathrm{CDCl}_{3}\right): \delta=10.12(\mathrm{~s}, 1 \mathrm{H}), 8.04\left(\mathrm{~d},{ }^{3} J=6.5 \mathrm{~Hz}, 2 \mathrm{H}\right), 7.83,\left(\mathrm{~d},{ }^{3} \mathrm{~J}=7.3 \mathrm{~Hz}\right.$, 1H), $7.76\left(\mathrm{~d},{ }^{3} \mathrm{~J}=6.7 \mathrm{~Hz}, 2 \mathrm{H}\right), 7-67-7-74(\mathrm{~m}, 1 \mathrm{H}), 7.57\left(\mathrm{~d},{ }^{3} \mathrm{~J}=7.6 \mathrm{~Hz}, 1 \mathrm{H}\right), 7.54(\mathrm{~s}, 1 \mathrm{H}) \mathrm{ppm}$. 13C-NMR $(101$ $\left.\mathrm{MHz}, \mathrm{CDCl}_{3}\right): \delta=191.8,144.0,144.0,136.2,134.0,133.1,130.1,130.1,129.6,128.6,118.3,111.3$ ppm. Anal. Calcd for $\mathrm{C}_{14} \mathrm{H}_{9} \mathrm{NO}: \mathrm{C}, 81.1 ; \mathrm{H}, 4.3 ; \mathrm{N}, 6.7$. Found: $\mathrm{C}, 80.9 ; \mathrm{H}, 4.0 ; \mathrm{N}, 6.4$. MS (Ion trap, EI): m/z $(\%)=207\left[\mathrm{M}^{+}\right]$ (55), 206 (100), 178 (25), 151 (18), 50 (6). (The data correspond to those reported in the literature: J. Kristensen, M. Lysén, P. Vedsø, M. Begtrup, Org. Lett. 2001, 3, 1435-1436.) 
Large scale procedure for the synthesis 2-cyano-4'-methylbiphenyl (4a) [CAS: 114772-53-1]. An oven-dried flask was equipped with an internal thermometer, a dropping funnel filled with molecular sieves, a condenser, and charged with 2-cyanobenzoic acid $(809.2 \mathrm{mg}, 5.50 \mathrm{mmol})$, potassium carbonate $(855.2 \mathrm{mg}, 5.50 \mathrm{mmol}), 7.5 \mathrm{~mL}$ dry quinoline and $7.5 \mathrm{~mL}$ dry toluene. The reaction mixture was stirred for $1 \mathrm{~h}$ at $80{ }^{\circ} \mathrm{C}$, refluxed for $30 \mathrm{~min}$., then the toluene was removed in vacuo. After flushing the vessel with alternating vacuum and nitrogen purge cycles, copper(II) oxide $(59.7 \mathrm{mg}, 0.75 \mathrm{mmol})$, potassium fluoride $(145.3 \mathrm{mg}, 2.50 \mathrm{mmol})$ [these compounds were dried before for $3 \mathrm{~h}$ at $120{ }^{\circ} \mathrm{C}$ under high vacuum], 1,10-phenanthroline (135.2 $\left.\mathrm{mg}, 0.75 \mathrm{mmol}\right)$, 4-bromotoluene (1733.2 mg, $7.50 \mathrm{mmol}$ ), palladium(II) bromide (26.6 mg, $0.10 \mathrm{mmol})$, triphenylphosphine $(78.7 \mathrm{mg}, 0.30 \mathrm{mmol})$ were added. The vessel was lowered into an oil bath and heated to $190{ }^{\circ} \mathrm{C}$. The temperature inside remained constant at $160^{\circ} \mathrm{C}$. After stirring the reaction mixture for $24 \mathrm{~h}$, it was allowed to cool to room temperature. The solution was acidified with aqueous $\mathrm{HCl}$ solution $(1 \mathrm{~N}, 75 \mathrm{~mL})$ and extracted repeatedly with ethyl acetate $(40 \mathrm{~mL}$ portions). The combined organic layers were washed twice with aqueous $\mathrm{HCL}(1 \mathrm{~N}, 75 \mathrm{~mL})$, saturated $\mathrm{NaHCO}_{3}$ and brine, dried over $\mathrm{MgSO}_{4}$ and filtered. The volatiles were removed in vacuo, and the residue was purified by Kugelrohr-distillation, yielding $\mathbf{4 a}$ as a yellow solid (556.4 mg, $58 \%$ ).

Large scale procedure for the synthesis 2-cyano-4'formylbiphenyl (4b) [CAS: 135689-93-9]. An ovendried flask was equipped with an internal thermometer, a dropping funnel filled with molecular sieves, a condenser, and charged with 2-cyanobenzoic acid $(735.6 \mathrm{mg}, 5.00 \mathrm{mmol})$, potassium carbonate $(691.0 \mathrm{mg}$, $5.00 \mathrm{mmol}$ ), $7.5 \mathrm{~mL}$ dry quinoline and $7.5 \mathrm{~mL}$ dry toluene. The reaction mixture was stirred for $1 \mathrm{~h}$ at $80{ }^{\circ} \mathrm{C}$, refluxed for $30 \mathrm{~min}$., then the toluene was removed in vacuo. After flushing the vessel with alternating vacuum and nitrogen purge cycles, copper(II) oxide $(59.7 \mathrm{mg}, 0.75 \mathrm{mmol})$, potassium fluoride $(145.3 \mathrm{mg}, 2.50 \mathrm{mmol})$ [these compounds were dried before for $3 \mathrm{~h}$ at $100{ }^{\circ} \mathrm{C}$ under high vacuum], 1,10-phenanthroline (135.2 $\mathrm{mg}$, $0.75 \mathrm{mmol}$ ), 1-bromo-(4-dimethoxymethyl)benzene (1733.2 $\mathrm{mg}, 7.50 \mathrm{mmol}$ ), palladium(II) bromide (26.6 $\mathrm{mg}$, $0.10 \mathrm{mmol})$ and triphenylphosphine $(26.2 \mathrm{mg}, 0.10 \mathrm{mmol})$ were added. The vessel was lowered into an oil bath and heated to $190{ }^{\circ} \mathrm{C}$. The temperature inside remained constant at $160{ }^{\circ} \mathrm{C}$. After stirring the reaction mixture for $24 \mathrm{~h}$, it was allowed to cool to room temperature, $50 \mathrm{~mL}$ ethyl acetate were added, the solution was acidified with aqueous $\mathrm{HCl}$ solution $(1 \mathrm{~N}, 75 \mathrm{~mL})$ and heated at $50{ }^{\circ} \mathrm{C}$ under stirring for $1 \mathrm{~h}$. The organic layer was seperated, washed with aqueous $\mathrm{HCL}$ solution $(1 \mathrm{~N}, 50 \mathrm{~mL})$, saturated $\mathrm{NaHCO}_{3}$ and brine, dried over $\mathrm{MgSO}_{4}$ and filtered. The volatiles were removed in vacuo, and the residue was purified by column chormatography $\left(\mathrm{SiO}_{2}\right.$, ethyl acetate / hexane 3:2), yielding $\mathbf{4 b}$ as a light yellow solid (992.8 mg, $78 \%$ ). 


\section{Representative procedure for the Valsartan synthesis}

4'-Bromomethyl-2-cyanobiphenyl (4c) [CAS: 114772-54-2]; An oven-dried $20 \mathrm{~mL}$ crimp top vial equipped with a septum cap was charged with 2-cyano-4'-methylbiphenyl $(138.5 \mathrm{mg}, 0.72 \mathrm{mmol}), \mathrm{N}$-bromosuccinimide (99.5 mg, $0.56 \mathrm{mmol})$, AIBN $(2.0 \mathrm{mg}, 0.01 \mathrm{mmol})$, dry cyclohexane $(1.5 \mathrm{~mL})$ and $\mathrm{CCl}_{4}(3 \mathrm{~mL})$. The reaction mixture was heated for $18 \mathrm{~h}$ at $75^{\circ} \mathrm{C}$. The solvent was removed under reduced pressure and the crude product was purified by column chromatography $\left(\mathrm{SiO}_{2}\right.$, ethyl acetate / hexane 3:7). The resulting solid was recrystallized with 4 drops ethyl acetate and hexane to yield compound $\mathbf{4 c}$ as white crystals $(88.6 \mathrm{mg}, 45 \%)$. 1H-NMR (400 MHz, $\left.\mathrm{CDCl}_{3}\right): \delta=7.80\left(\mathrm{~d},{ }^{3} J=7.8 \mathrm{~Hz}, 1 \mathrm{H}\right), 7.65-7.71(\mathrm{~m}, 1 \mathrm{H}), 7.52-7.59(\mathrm{~m}, 5 \mathrm{H}), 7,48\left(\mathrm{~d},{ }^{3} J=7.6 \mathrm{~Hz}, 1 \mathrm{H}\right), 4.58(\mathrm{~s}$, 2H) ppm. 13C-NMR (101 MHz, $\left.\mathrm{CDCl}_{3}\right): \delta=144.8,138.4,133.8,132.8,130.0,129.4,129.2,127.7,118.5,118.4$, 111.5, 32.6 ppm. Anal. Calcd for $\mathrm{C}_{14} \mathrm{H}_{10} \mathrm{BrN}$ : C, 61.8; H, 3.7; N, 5.1. Found: C, 61.8; H, 3.7; N, 5.1. (The data correspond to those reported in the literature: D. Carini, J. Duncia, P. Aldrich, A. Chiu, A. Johnson, M. Pierce, W. Price, J. Santella, G. Wells, R. Wexler, P. Wong, SE. Yoo, P. Timmermans, J. Med. Chem. 1991, 34, 2525-2547.)

$N$-[(2'-Cyanobiphenyl-4-yl)-methyl]-(L)-valine methyl ester (6) [CAS: 137863-89-9]; was prepared according to the literature [P. Bühlmayer, F. Ostermayer, T. Schmidlin, Eur. Pat. Appl., EP443983, 1991]. An oven-dried flask was charged with 2-cyano-4'formylbiphenyl $\mathbf{4 b}(1.99 \mathrm{~g}, 9.64 \mathrm{mmol}), L$-valine methyl ester hydrochloride $(3.02 \mathrm{~g}, 18.00 \mathrm{mmol})$, ground $3 \AA$ molecular sieves $(2.50 \mathrm{~g}$, dried in the microwave) and dry THF $(100 \mathrm{~mL})$. The reaction mixture was stirred at room temperature for 60h. Afterwards, the solution was cooled to $0{ }^{\circ} \mathrm{C}$ and sodium cyanoborohydride $(628.4 \mathrm{mg}, 10.00 \mathrm{mmol})$ dissolved in $4 \mathrm{~mL}$ EtOH was added. The mixture was again stirred at $23{ }^{\circ} \mathrm{C}$ for $24 \mathrm{~h}$, then the molecular sieves were filtered off over Celite ${ }^{\circledR}$ and the solution was washed with saturated aqueous $\mathrm{NaHCO}_{3}$ (ethyl acetate was added for a better separation) and dried over $\mathrm{MgSO}_{4}$. The organic layer was restricted and purified by column chromatography $\left(\mathrm{SiO}_{2}, \mathrm{DCM}, 1 \% \mathrm{MeOH}\right)$, to yield compound 5 as a yellowish oil $(2.8 \mathrm{~g}, 90 \%)$. 1H-NMR $\left(400 \mathrm{MHz}, \mathrm{CDCl}_{3}\right): \delta=7.73-7.80(\mathrm{~m}, 1 \mathrm{H}), 7.65\left(\mathrm{dd},{ }^{3} J\right.$ $=7.6,1.5 \mathrm{~Hz}, 1 \mathrm{H}), 7.45-7.55(\mathrm{~m}, 6 \mathrm{H}), 3.92\left(\mathrm{~d},{ }^{3} J=13.5 \mathrm{~Hz}, 1 \mathrm{H}\right), 3.76(\mathrm{~s}, 3 \mathrm{H}), 3.67\left(\mathrm{~d},{ }^{3} J=13.2 \mathrm{~Hz}, 1 \mathrm{H}\right), 3.08$ $\left(\mathrm{d},{ }^{3} J=6.2 \mathrm{~Hz}, 1 \mathrm{H}\right), 1.97(\mathrm{~s}, 1 \mathrm{H}), 1.83(\mathrm{~s}, 1 \mathrm{H}), 0.99\left(\mathrm{t},{ }^{3} J=6.5 \mathrm{~Hz}, 6 \mathrm{H}\right) \mathrm{ppm} .13 \mathrm{C}-\mathrm{NMR}\left(101 \mathrm{MHz}, \mathrm{CDCl}_{3}\right): \delta=$ 175.5, 145.5, 141.0., 136.9, 133.7, 132.6, 130.0, 128.7, 128.5, 127.3, 118.6, 111.5, 77.2, 66.9, 52.3, 31.7, 19.3, 18.6, ppm. Anal. Calcd for $\mathrm{C}_{20} \mathrm{H}_{22} \mathrm{~N}_{2} \mathrm{O}_{2}$ : C,74.5; H, 6.9; N, 8.7. Found: C, 74.1; H, 6.9; N, 8.6.

$N$-Pentanoyl- $N$-[(2'-cyanobiphenyl-4-yl-)-methyl]-(L)-valine methyl ester (8) [CAS: 137863-90-2]; An oven-dried flask was filled with $N$-[(2'-cyanobiphenyl-4-yl)-methyl]-( $L)$-valine methyl ester 6 (1.0 g, $3.1 \mathrm{mmol})$ dissolved in dichloromethane $(30 \mathrm{~mL})$ and pyridine $(474.6 \mathrm{mg}, 6.0 \mathrm{mmol})$ and then cooled to $0{ }^{\circ} \mathrm{C}$. Afterwards valeroyl chloride $(723.5 \mathrm{mg}, 6 \mathrm{mmol})$ in dichloromethane was added slowly drop by drop under stirring and the reaction mixture was stirred over-night and later heated by $40{ }^{\circ} \mathrm{C}$ for $2 \mathrm{~h}$. The solvent was removed and the crude product was taken up with diethyl ether, washed with saturated aqueous $\mathrm{NaHCO}_{3}$ and brine, the organic layer was restricted and the created solid was purified by column chromatography $\left(\mathrm{SiO}_{2}, \mathrm{DCM} /{ }^{i} \mathrm{PrOH}=9.5 / 0.5\right)$, to yield compound 6 as a yellow oil $(1.2 \mathrm{~g}, 98 \%)$. 1H-NMR $\left(600 \mathrm{MHz}, \mathrm{CDCl}_{3}\right)$ mixture of rotamers: $\delta=7.72-7.76(\mathrm{~m}$, $1 \mathrm{H}), 7.59-7.65(\mathrm{~m}, 1 \mathrm{H}), 7.39-7.53(\mathrm{~m}, 4 \mathrm{H}), 7.27-7.30(\mathrm{~m}, 2 \mathrm{H}), 5.07$ and $4.25\left(2 \mathrm{~d},{ }^{3} J=15.45 \mathrm{~Hz}, 1 \mathrm{H}\right), 4.96$ and $4.05\left(2 \mathrm{~d},{ }^{3} J=10.40, \mathrm{~Hz}, 1 \mathrm{H}\right), 4.64-4.71(\mathrm{~m}, 1 \mathrm{H}), 3.44(\mathrm{~s}, 2 \mathrm{H}), 3.35(\mathrm{~s}, 1 \mathrm{H}), 2.58-2.60$ and $2.36-2.47(2$ $\mathrm{m}, 1 \mathrm{H}), 2.26-2.35(\mathrm{~m}, 2 \mathrm{H}), 1.73-1.74(\mathrm{~m}, 1 \mathrm{H}), 1.60-1.64(\mathrm{~m}, 1 \mathrm{H}), 1.35-1.40(\mathrm{~m}, 1 \mathrm{H}), 1.27-1.30(\mathrm{~m}, 1 \mathrm{H})$, $0.95-0.98(\mathrm{~m}, 4 \mathrm{H}), 0.84-0.90(\mathrm{~m}, 5 \mathrm{H})$ ppm. 13C-NMR $\left(150 \mathrm{MHz}, \mathrm{CDCl}_{3}\right): \delta=174.6 ., 174.3,171.1,170.3$, 145.3, 144.8, 138.7, 138.0, 137.1, 136.6, 133.8, 133.7, 132.9, 132.8, 130.1, 129.1, 128.5, 127.9, 127.7, 127.5, 126.3, 118.5, 111.3, 65.8, 61.7, 52.1, 51.7, 48.1, 45.3, 33.4, 27.8, 27.6, 27.5, 22.6, 22.5, 19.9, 18.7, 13.9 ppm. Anal. Calcd for $\mathrm{C}_{25} \mathrm{H}_{30} \mathrm{~N}_{2} \mathrm{O}_{3}$ : C,73.8; H, 7.4; N, 7.0. Found: C, 73.7; H, 7.4; N, 6.9. 
$N$-Pentanoyl- $N$-[[2'-(1H-tetrazole-5-yl)-[1,1'-biphenyl]-4-yl]-methyl]-(L)-valine methyl ester (1c) [CAS: 137863-17-3]; An oven-dried flask was filled with $N$-pentanoyl- $N$-[(2'-cyanobiphenyl-4-yl-)-methyl]-(L)-valine methyl ester $8(745.0 \mathrm{mg}, 1.8 \mathrm{mmol})$, sodium azide $(234 \mathrm{mg}, 3.6 \mathrm{mmol})$, tributyltin chloride $(1.2 \mathrm{~g}, 3.6 \mathrm{mmol})$, tetrabutylammonium bormide $(12.9 \mathrm{mg}, 0.04 \mathrm{mmol})$ and toluene $(20 \mathrm{~mL})$. The reaction mixture was refluxed for $72 \mathrm{~h}$. After cooling to room temperature the solution was charged with $1.8 \mathrm{~mL}$ acetic acid ( $1 \mathrm{~mL}$ acid, $2 \mathrm{~mL}$ water) and stirred over-night. The organic phase was separated, concentrated and purified by column chromatography $\left(\mathrm{SiO}_{2}, \mathrm{DCM} /(\mathrm{DCM}, 10 \% \mathrm{MeOH})=1 / 1\right)$. A light yellow solid was obtained $(453 \mathrm{mg}, 55 \%) .1 \mathrm{H}-\mathrm{NMR}(600$ $\left.\mathrm{MHz}, \mathrm{CDCl}_{3}\right)$ mixture of rotamers: $\delta=7.96-8.04(\mathrm{~m}, 1 \mathrm{H}), 7.58-7.62(\mathrm{~m}, 1 \mathrm{H}), 7.52-7.54(\mathrm{~m}, 1 \mathrm{H}), 7.41-7.45$ $(\mathrm{m}, 1 \mathrm{H}), 7.07-7.19(\mathrm{~m}, 4 \mathrm{H}), 4.97$ and $4,25\left(2 \mathrm{~d},{ }^{3} J=15.45 \mathrm{~Hz}, 1 \mathrm{H}\right), 4.87$ and $4.05\left(2 \mathrm{~d},{ }^{3} J=10.63 \mathrm{~Hz}, 1 \mathrm{H}\right), 4.67$ and $4.62\left(2 \mathrm{~d},{ }^{3} J=17.59,1 \mathrm{H}\right), 3.46(\mathrm{~s}, 1.5 \mathrm{H}), 3.41(\mathrm{~s}, 1.4 \mathrm{H}), 2.55-2.60$ and $2.39-2.46(2 \mathrm{~m}, 1 \mathrm{H}), 2.27-2.38$ and $2.19-2.24(2 \mathrm{~m}, 2 \mathrm{H}), 1.55-1.68(\mathrm{~m}, 2 \mathrm{H}), 1.35-1.40(\mathrm{~m}, 1 \mathrm{H}), 1.25-1.32(\mathrm{~m}, 1 \mathrm{H}), 0.85-1.01(\mathrm{~m}, 9 \mathrm{H})$ ppm. 13C-NMR (150 MHz, $\left.\mathrm{CDCl}_{3}\right): \delta=174.9,174.9,171.3,170.3,140.9,138.6,138.1,137.8,137.2,131.3$, $130.8,130.7,130.7,129.3,128.9,128.2,128.1,127.9,126.5,122.6,66.0,61.8,52.2,51.9,48.2,45.6,33.5,27.6$, 27.6, 27.3, 22.5, 19.9, 18.8, 18.7, 13.9 ppm. Anal. Calcd for $\mathrm{C}_{25} \mathrm{H}_{31} \mathrm{~N}_{5} \mathrm{O}_{3}$ : C,66.8; $\mathrm{H}, 6.9 ; \mathrm{N}, 15.6$. Found: C,66.5; $\mathrm{H}, 6.9 ; \mathrm{N}, 15.2$.

$N$-Pentanoyl- $N$-[[2'-(1H-tetrazole-5-yl)-[1,1'-biphenyl]-4-yl]-methyl]-(L)-valine (Valsartan) (1b) [CAS: 137862-53-4]; An oven-dried flask was charged with $N$-pentanoyl- $N$-[[2'-(1H-tetrazole-5-yl)-[1, 1'-biphenyl]-4yl]-methyl]-(L)-valine methyl ester 1c $(400.0 \mathrm{mg}, 0.88 \mathrm{mmol})$ dissolved in diethyl ether, dist. water $(7 \mathrm{~mL})$ and aqueous $\mathrm{NaOH}(1 \mathrm{~N}, 3 \mathrm{~mL})$ and stirred over-night at room temperature. The organic phase was separated and the aqueous layer was acidified with aqueous $\mathrm{HCl}$ solution $(3 \mathrm{~N})$ until a $\mathrm{pH}$ of 3 was reached. Extraction was carried out with diethyl ether followed by drying and evaporating to dryness, recrystallized from ethyl acetate and pentane to furnish the desired product as a white solid $(380.2 \mathrm{mg}, 99 \%)$. 1H-NMR $\left(400 \mathrm{MHz}, \mathrm{CD}_{2} \mathrm{Cl}_{2}\right) \underline{\text { mixture }}$ of rotamers: major rotamer: $\delta=8.03-8.05(\mathrm{~m}, 1 \mathrm{H}), 7.64-7.66(\mathrm{~m}, 1 \mathrm{H}), 7.59-7.62(\mathrm{~m}, 1 \mathrm{H}), 7.52-7.55(\mathrm{~m}$, $1 \mathrm{H}), 7.23-7.27(\mathrm{~m}, 4 \mathrm{H}), 5.03\left(\mathrm{~d},{ }^{3} J=15.31 \mathrm{~Hz}, 1 \mathrm{H}\right), 4.25\left(\mathrm{~d},{ }^{3} \mathrm{~J}=15.32 \mathrm{~Hz}, 1 \mathrm{H}\right), 3.41-3.44(\mathrm{~m}, 1 \mathrm{H}), 2.71-$ $2.77(\mathrm{~m}, 1 \mathrm{H}), 2.61-2.65(\mathrm{~m}, 2 \mathrm{H}), 1.70-1.78(\mathrm{~m}, 2 \mathrm{H}), 1.41-1.50(\mathrm{~m}, 2 \mathrm{H}), 0.96-1.01(\mathrm{~m}, 9 \mathrm{H})$. minor rotamer: $\delta=7.92-7.94(\mathrm{~m}), 7.62-7.67(\mathrm{~m}), 7.54-7.56(\mathrm{~m}), 7.47-7.49(\mathrm{~m}), 7.11-7.19(\mathrm{~m}), 6.98-7.00(\mathrm{~m}), 5.17(\mathrm{~d}$, $\left.{ }^{3} J=15.58\right), 4.09-4.15(\mathrm{~m}), 3.47-3.50(\mathrm{~m}), 2.51(\mathrm{~m}), 1.66-1.68(\mathrm{~m}), 1.36-1.40(\mathrm{~m}), 1.30(\mathrm{bs}, 1 \mathrm{H}), 0.86-$ 1.07 (m) ppm.13C-NMR (101 MHz, $\left.\mathrm{CD}_{2} \mathrm{Cl}_{2}\right): \delta=177.4,172.5,170.9,154.6,140.5,139.3,135.4,131.2,130.9$, $130.5,129.8,128.7,128.4,128.3,123.2,60.3,34.3,33.4,27.3,26.8,22.5,22.4,20.8,19.6,19.2,19.0,18.4,14.0$, 13.7, 13.6 ppm. ESI-MS: $[\mathrm{M}+\mathrm{H}]^{+} 436,[\mathrm{M}+\mathrm{Na}]^{+} 459,[\mathrm{M}+\mathrm{K}]^{+} 475$. (The data correspond to those reported in the literature: J. L. Rafecas, A. Escale Riera, M. Queralt Ecija, A. Moyano, A. Comely, I. Casalprim, Int. Patent, WO200606721, 2006.) 
2-Cyanobenzoic acid (2c) [CAS: 3839-22-3]:

1H NMR (400 MHz, DMSO-D6) $\delta$ ppm 7.76 - 7.86 (m, 3 H) 7.93 - 8.02 (m, 1 H) 8.06 - 8.14 (m, 1 H)
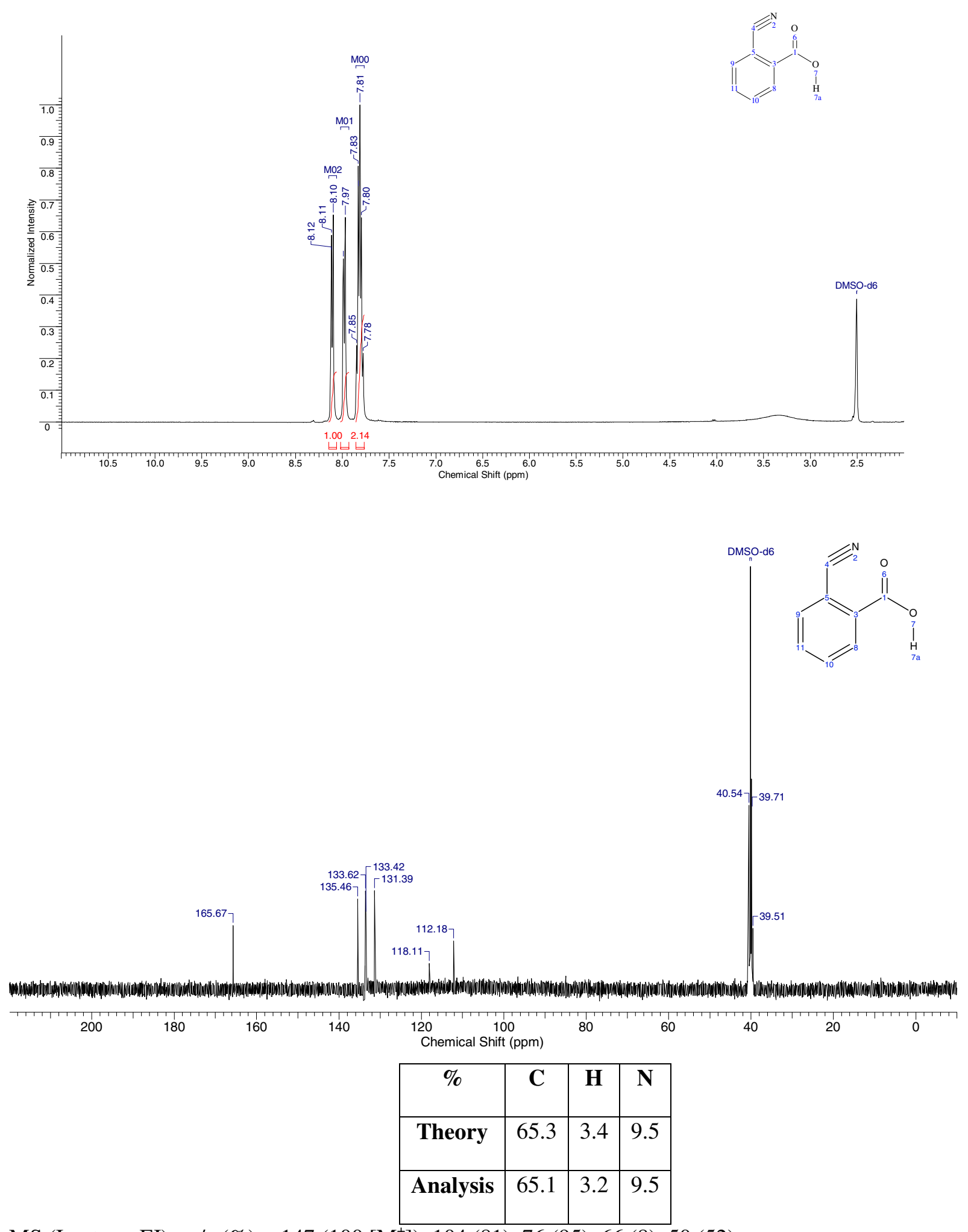

MS (Ion trap, EI): m/z (\%) = $147\left(100\left[\mathrm{M}^{+}\right]\right), 104$ (81), 76 (95), 66 (8), 50 (52). 
2-Cyano-4'-methylbiphenyl (4a) [CAS: 114772-53-1]:
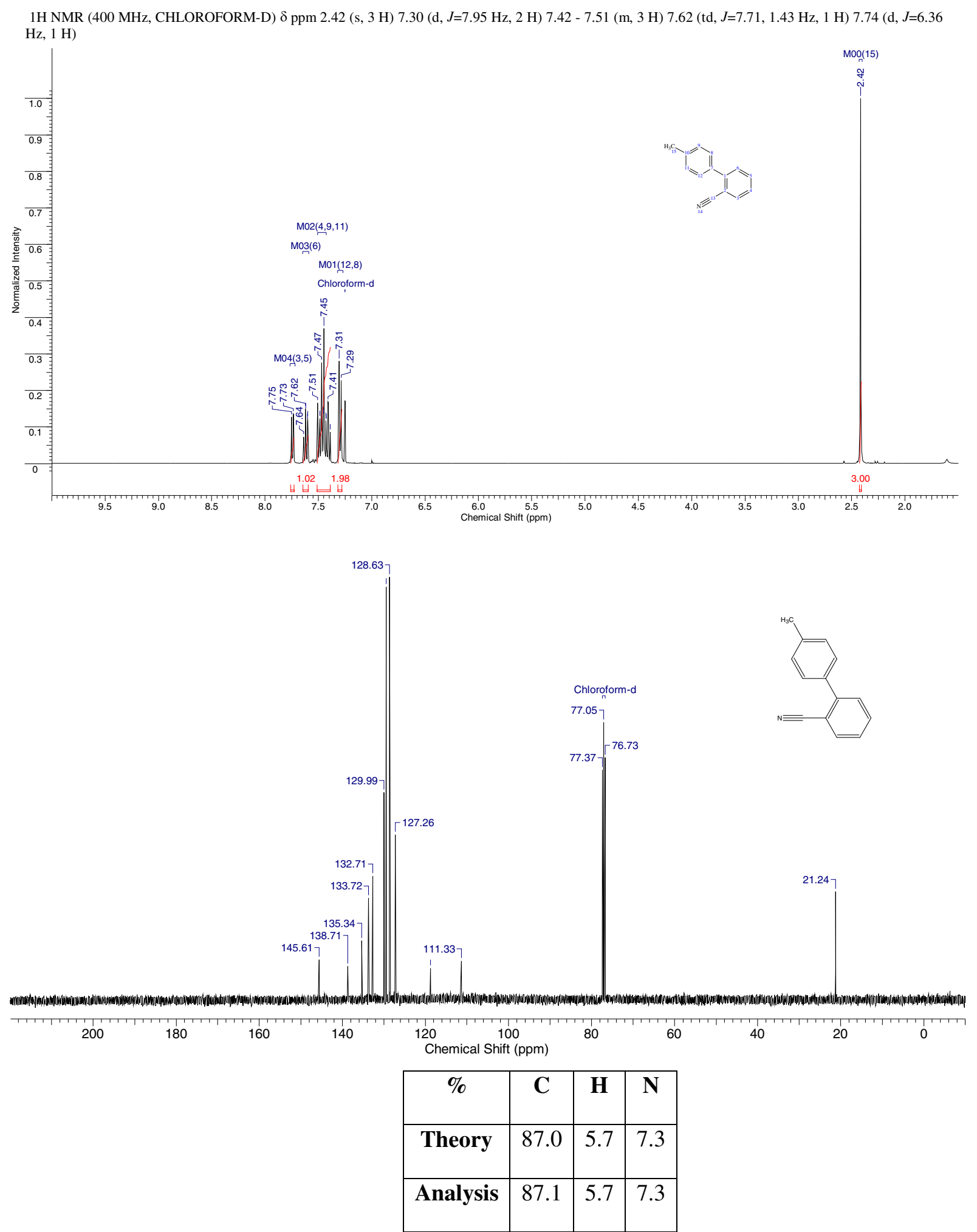

MS (Ion trap, EI): m/z (\%) = $193\left(100\left[\mathrm{M}^{+}\right]\right), 192$ (48), 165 (29), 139 (4), 91 (4), 75 (4), 50 (4). 


\section{2-Cyano-4'formylbiphenyl (4b) [CAS: 135689-93-9] :}

1H NMR (600 MHz, CHLOROFORM-D) $\delta$ ppm 7.54 (s, 1 H) 7.57 (d, J=7.63 Hz, 1 H) $7.67-7.74$ (m, 1 H) 7.76 (d, J=6.75 Hz, 2 H) 7.83 (d, J=7.34 Hz, 1 H) 8.04 (d, J=6.46 Hz, 2 H) 10.12 (s, $1 \mathrm{H})$
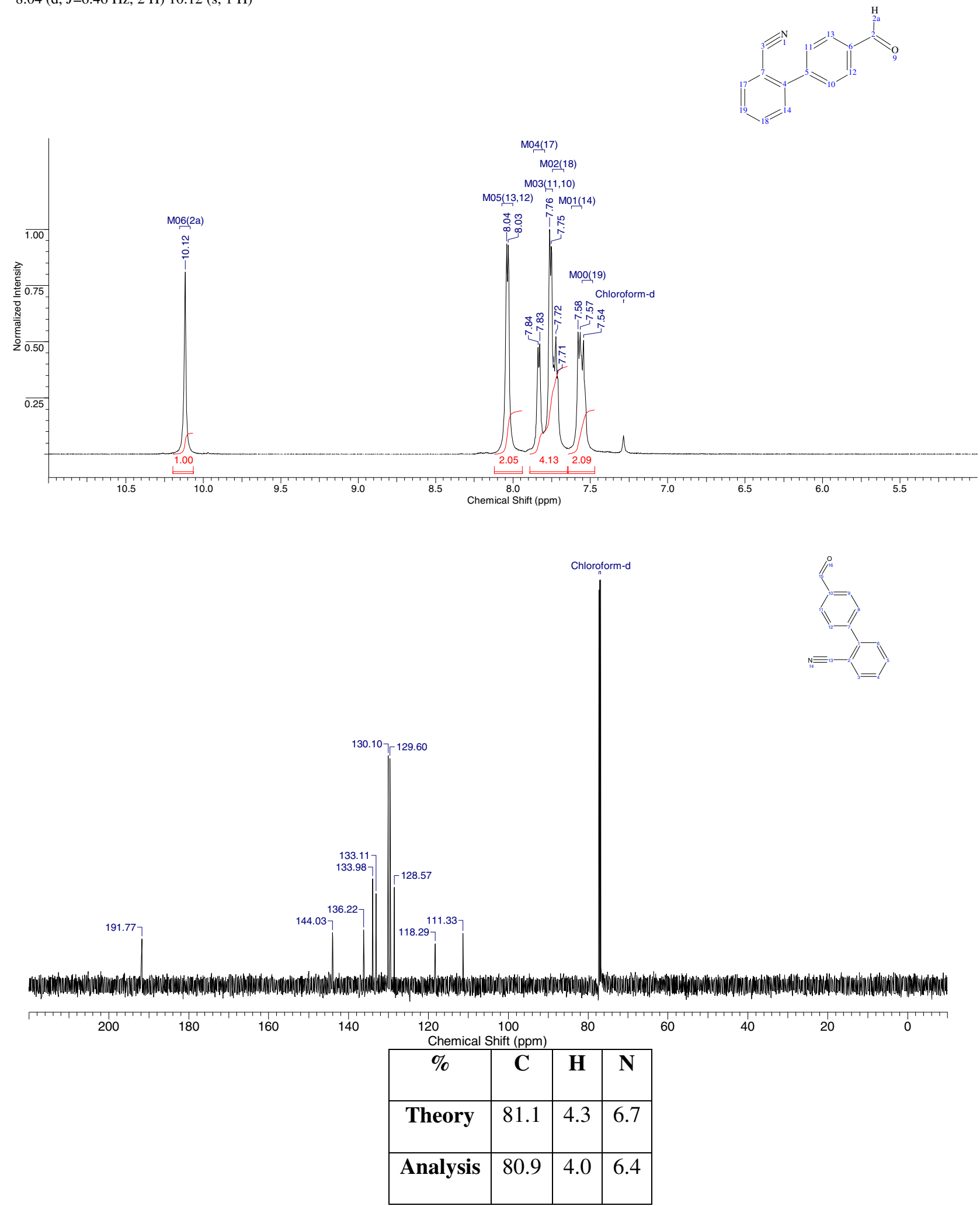

MS (Ion trap, EI): m/z (\%) = $207\left(55\left[\mathrm{M}^{+}\right]\right), 206$ (100), 178 (25), 151 (18), 125 (4), 75 (7), 50 (6). 


\section{4'-Bromomethyl-2-cyanobiphenyl (4c) [CAS: 114772-54-2]:}
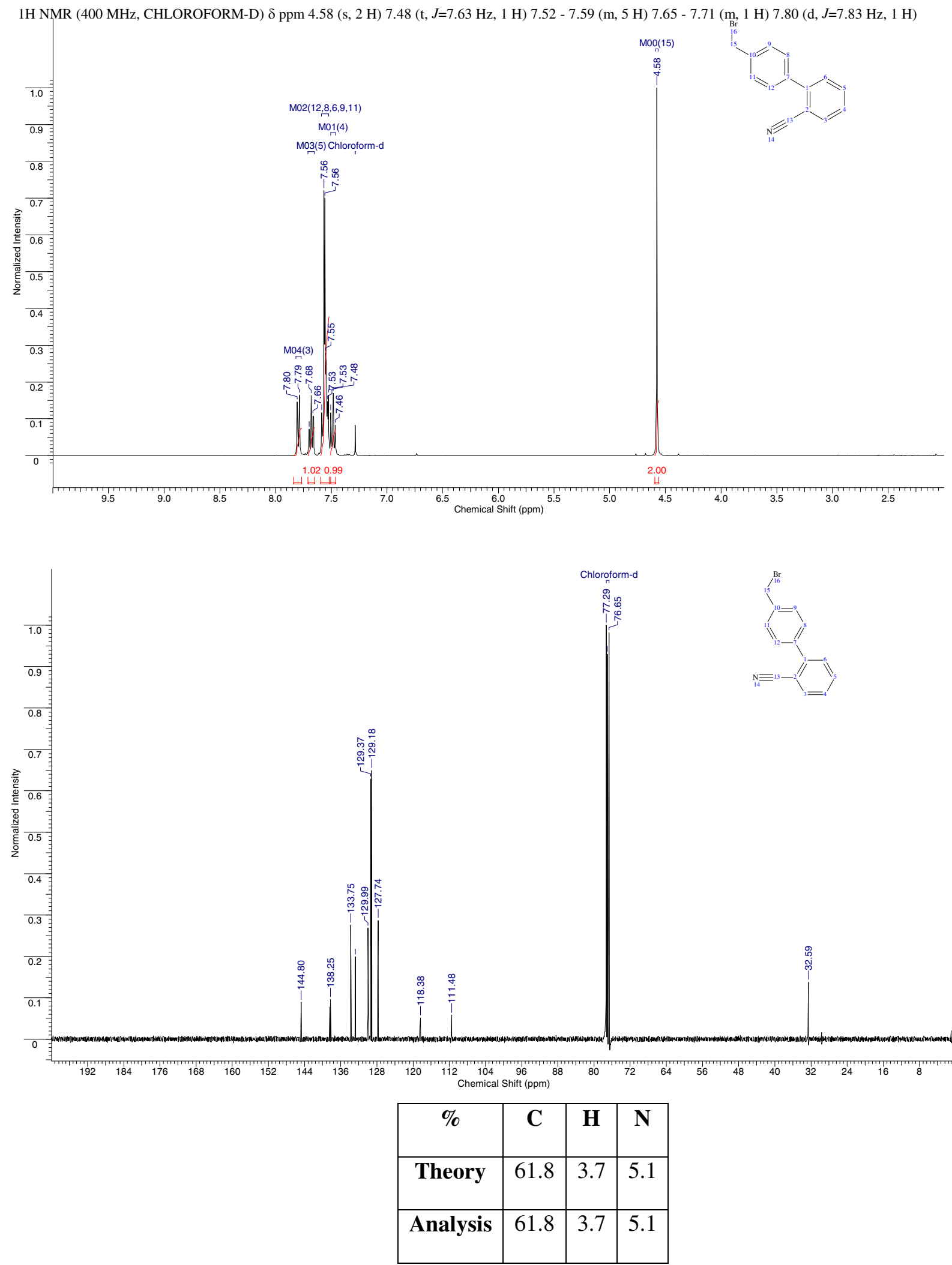


\section{$N$-[(2'-Cyanobiphenyl-4-yl)-methyl]-(L)-valine methyl ester (6) [CAS: 137863-89-9] :}
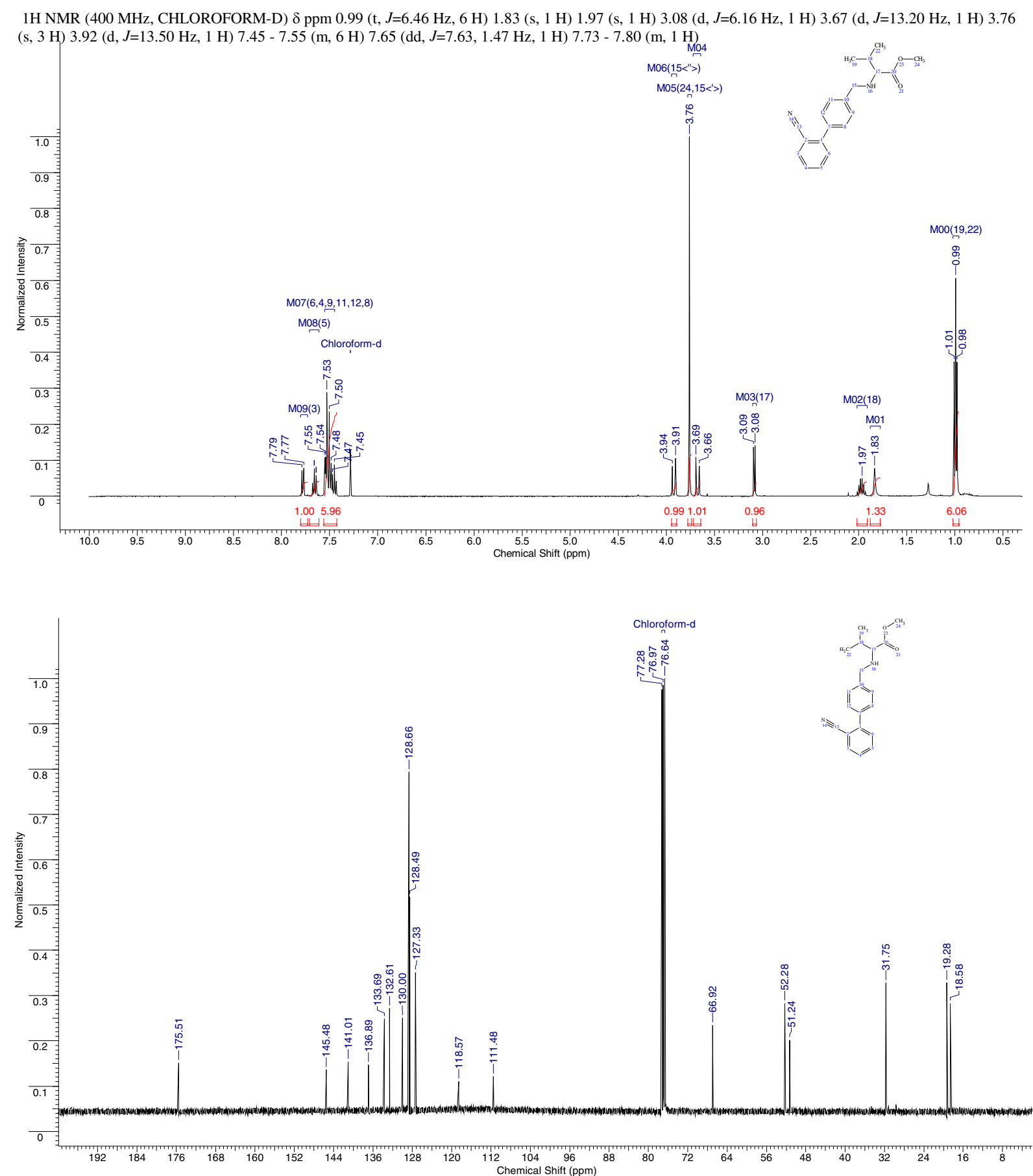

\begin{tabular}{|c|c|c|c|}
\hline$\%$ & $\mathbf{C}$ & $\mathbf{H}$ & $\mathbf{N}$ \\
\hline Theory & 74.5 & 6.9 & 8.7 \\
\hline Analysis & 74.1 & 6.9 & 8.6 \\
\hline
\end{tabular}


$N$-Pentanoyl- $N$-[(2'-cyanobiphenyl-4-yl-)-methyl]-(L)-valine methyl ester (8) [CAS: 137863-90-2] :
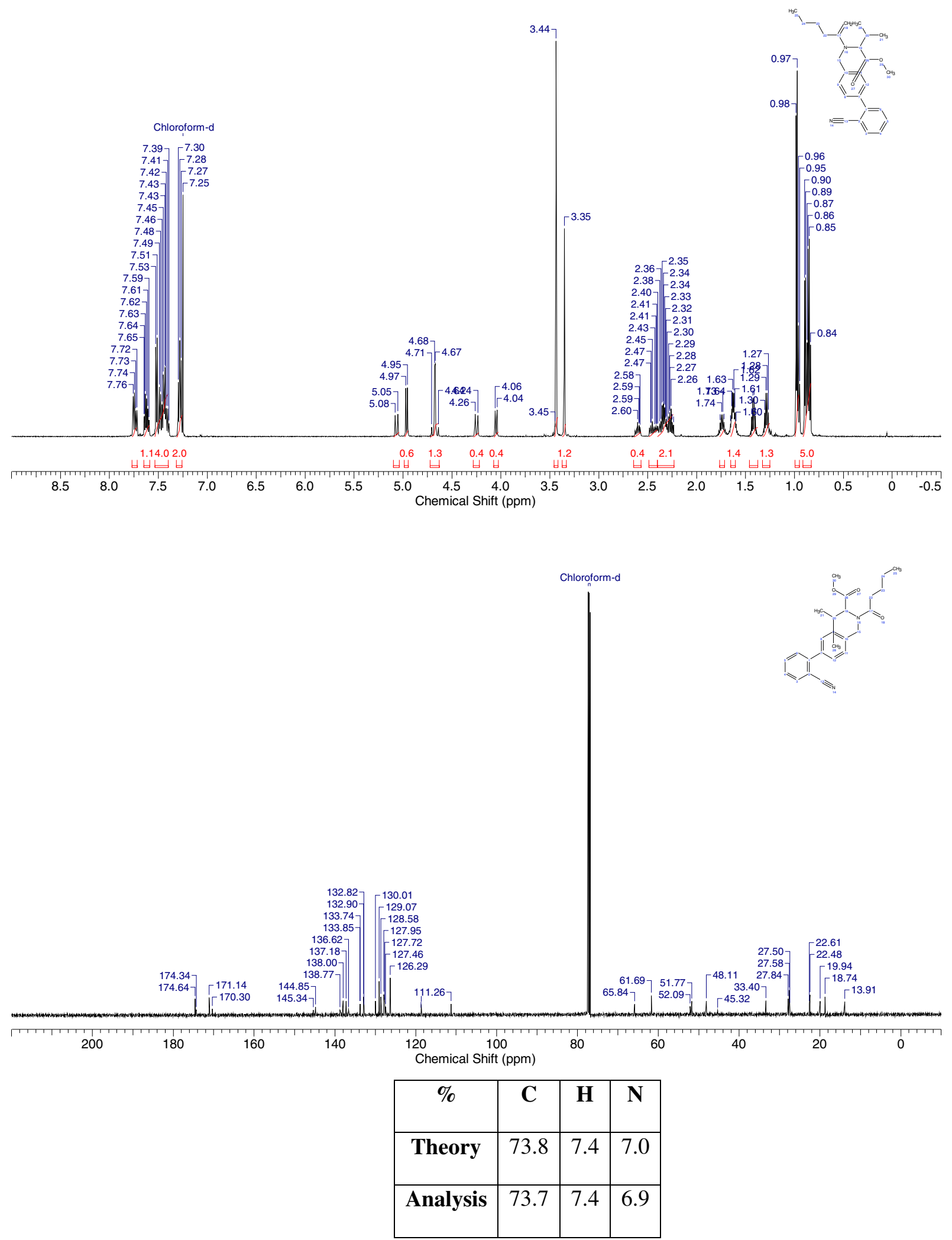
$N$-Pentanoyl- $N$-[[2'-(1H-tetrazole-5-yl)-[1, 1'-biphenyl]-4-yl]-methyl]-( $L)$-valine methyl ester (1c)

[CAS: 137863-17-3]:
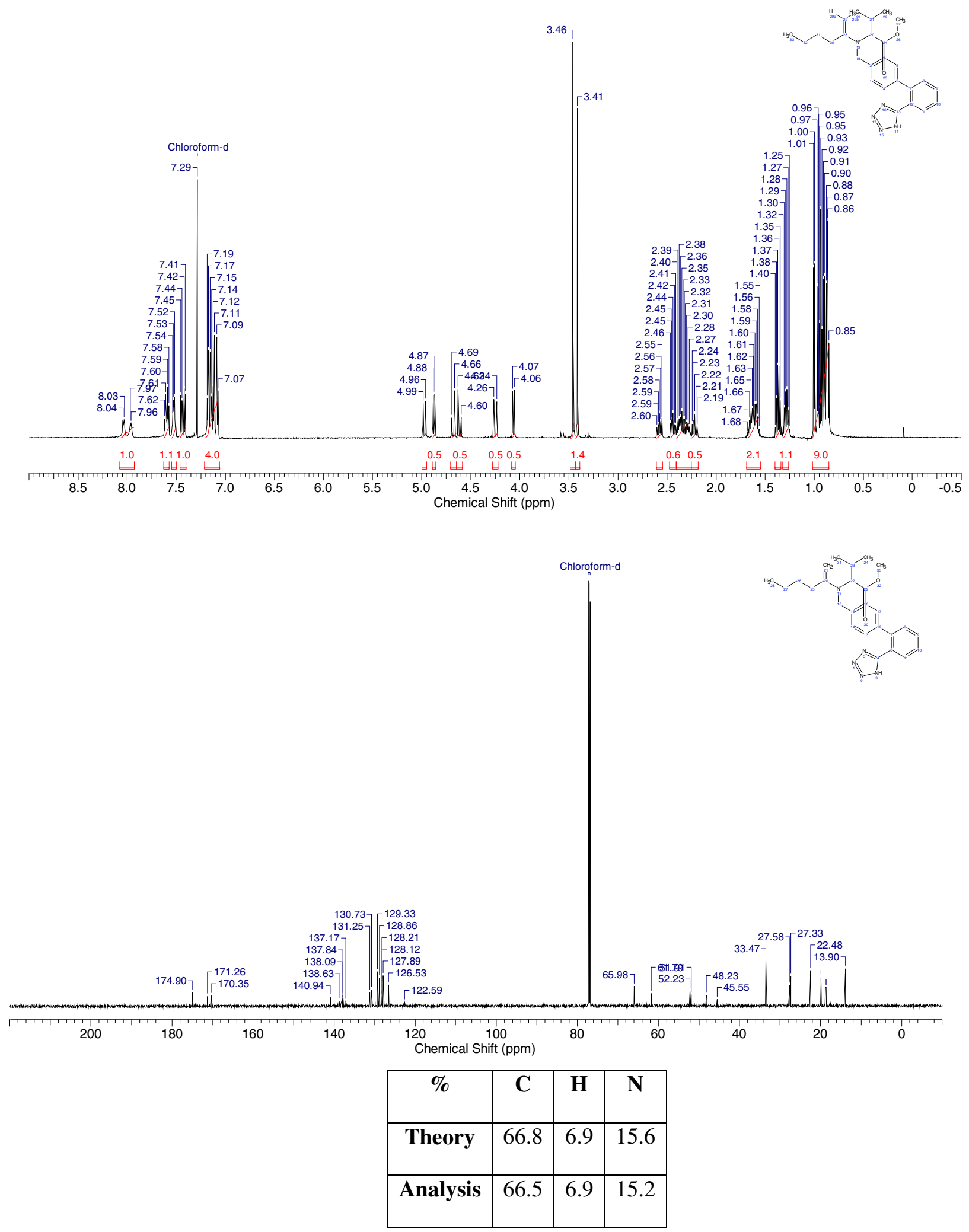


\section{2-53-4]:}
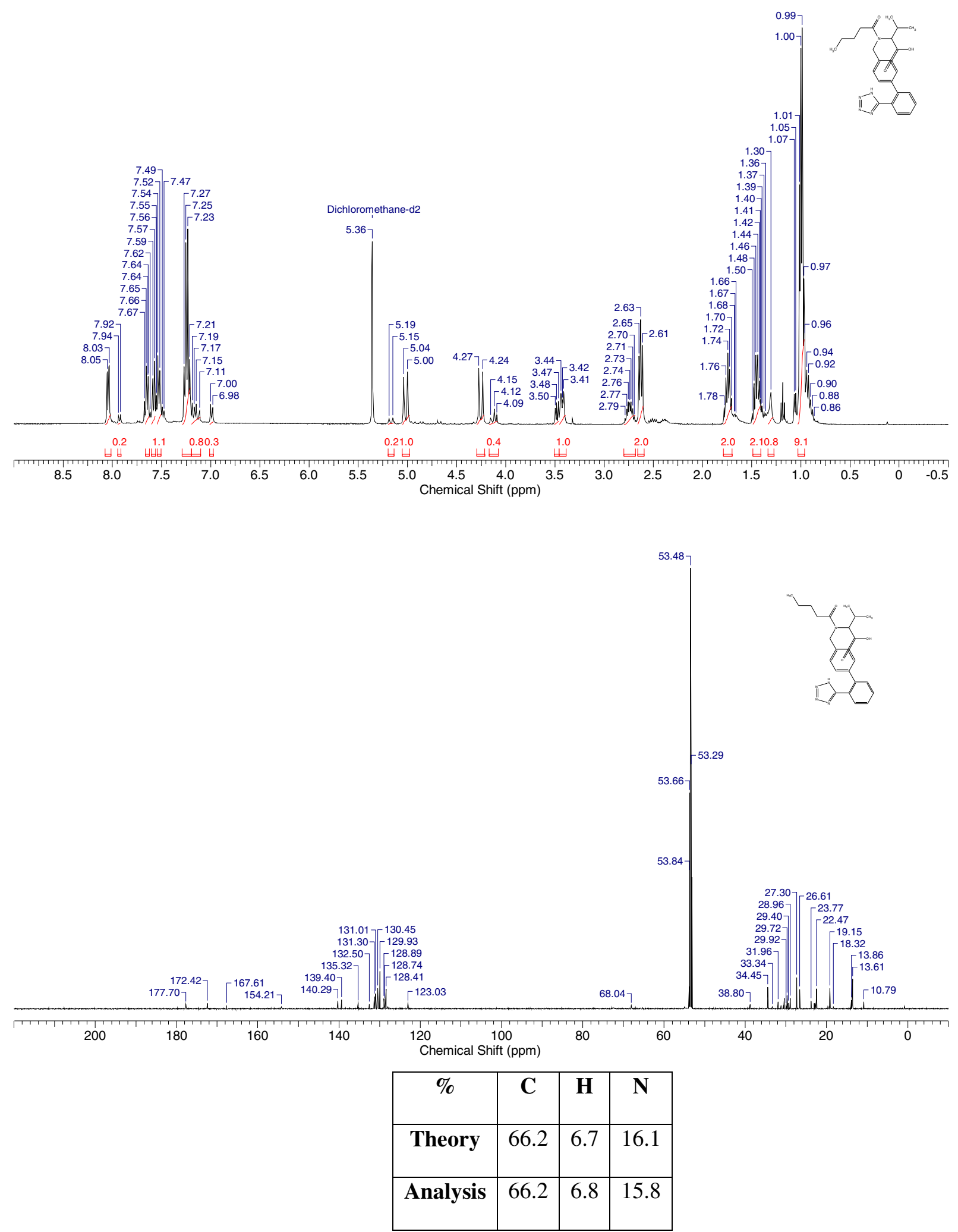